\title{
SELECTED OXIDATIVE STRESS PARAMETERS AFTER SINGLE AND REPEATED ADMINISTRATION OF OCTABROMODIPHENYL ETHER TO RATS
}

\author{
ELŻBIETA BRUCHAJZER, BARBARA FRYDRYCH, ANNA KILANOWICZ, ANDRZEJ SAPOTA, \\ and JADWIGA A. SZYMAŃSKA
}

Medical University of Lodz, Łódź, Poland

Department of Toxicology

\begin{abstract}
Objectives: Octabromodiphenyl ether (OctaBDE) was used as a flame retardant applied mostly in the manufacture of plastics utilized in the electrical and electronic industries. Owing to its long half-life and being regarded as an environmental pollutant, OctaBDE, like other polybrominated diphenyl ethers, has been classified as a persistent organic pollutant (POP). This study was carried out to assess the effects of oxidative stress (redox homeostasis) induced in rats by OctaBDE. Material and Methods: Female Wistar rats exposed intragastrically to OctaBDE at single (25, 200 or $2000 \mathrm{mg} / \mathrm{kg}$ b.w.), or repeated $(0.4,2,8,40$ or $200 \mathrm{mg} / \mathrm{kg} /$ day $)$ doses during 7-28 days were used in the experiment. Selected oxidative stress parameters were determined in the liver and blood serum. Results: Administration (single or repeated) of OctaBDE to rats resulted in the impaired redox homeostasis, as evidenced by the increased levels of reduced (GSH) and oxidized (GSSG) glutathione in the liver, the reduced total antioxidant status (TAS) in serum and the increased concentration of malondialdehyde (MDA) in the liver. After multiple doses of OctaBDE, elevated activity of glutathione transferase (GST) in the liver was also noted. Conclusions: After repeated administration of OctaBDE at the lowest dose $(0.4 \mathrm{mg} / \mathrm{kg} / \mathrm{day})$, changes were observed in the parameters (MDA, TAS, GSSG) indicative of oxidative stress.
\end{abstract}

Key words:

Oxidative stress, Rat, OctaBDE, Single and repeated administration

\section{INTRODUCTION}

Octabromodiphenyl ether (OctaBDE) was 1 of the 3 polybrominated diphenyl ethers (PBDEs) used as flame retardants. In 2004 in Europe, OctaBDE and pentabromodiphenyl ether (PentaBDE) were restricted on the marketing and use [1] mostly due to their classification in the group of persistent organic pollutants (POPs). Despite cessation of their use, many compounds belonging to POPs (e.g., dichloro-diphenyltrichloroethane - DDT, polychlorinated biphenyls - PCBs) have presented a significant environmental hazard for many decades. A similar situation may apply to PBDEs.

For almost forty years, OctaBDE has been used as a flame retardant in the domestic electrical and electronic equipment, mainly in the ABS (acrylonitrile butadiene styrene), HIPS (high impact polystyrene), PBT (polybutylene terephthalate) and polyamide products [2]. In 2001, the production of OctaBDE worldwide was reduced to approximately 3790 tons (including 610 tons in the European Union). This represented nearly $6 \%$ of

This study was supported by the Medical University of Lodz (Project No. 503/3-045-01/503-01, statutory activity).

Received: February 20, 2014. Accepted: June 19, 2014.

Corresponding author: E. Bruchajzer, Medical University of Lodz, Department of Toxicology, Faculty of Pharmacy, Muszyńskiego 1, 90-151 Łódź, Poland (e-mail: elzbieta.bruchajzer@umed.lodz.pl). 
all manufactured PBDEs (production of PentaBDE and DecaBDE was $11 \%$ and $83 \%$, respectively) [3].

The concentrations of OctaBDE in the natural environment are lower than those of other frequently used (decaand pentabromodiphenyl) ethers [2,4,5]. High lipophilicity of PBDEs causes that these compounds are found in the adipose tissue and in the food of animal origin (cow's milk, meat) and seafood (fish, shrimp).

OctaBDE may get into the human body mainly with food and with dust present in residential spaces. Breast-fed babies are the particularly exposed group. Over the recent 20-30 years, the levels of PBDEs in human tissues have continued to increase. People living in North America showed tissue PBDE concentrations even about 2 orders of magnitude higher than those living in Europe or Japan. It is most likely that a higher production and use of PBDEs and dietary habits are responsible for this situation [2,6,7].

PBDEs, including OctaBDE, were found in the serum of workers involved in the utilization of electrical and electronic equipment (electronic dismantlers). OctaBDE concentrations in the serum of occupationally exposed people from China were several times higher than those in Europeans [8].

According to studies carried out by the producers (Great Lake Chemical Corporation and Ethyl Corporation), the median values of the lethal dose $\left(\mathrm{LD}_{50}\right)$ for rats ranges from over 5000 to more than $10000 \mathrm{mg} / \mathrm{kg}$ body weight (b.w.). This means that OctaBDE, like other PBDEs, is not classified as a toxic substance [2]. However, adverse effects have been observed after a long-term exposure to PBDEs. People employed in the e-waste dismantling, as well as rats receiving PBDEs showed abnormalities in the functioning of the thyroid gland [2,9-12]. Like other compounds of the POP group (PCBs, DDT), PBDEs are classified as endocrine disruptors $[12,13]$. The observations in women show that PBDEs, including OctaBDE (BDE-197), may extend an average menstrual cycle $>32$ days [14]. After administration of OctaBDE during pregnancy, learning disorders and hyperactivity were also observed during the 2nd month of mice's lifetime [15].

PBDEs caused changes in the activity of enzymes implicated in the biotransformation of xenobiotics. Administration of OctaBDE was responsible for the enlargement of the liver and the increase in P-450 cytochrome and UDPglukuronyl transferase levels [16,17]. Exposure to PBDEs enhanced the levels of individual families and subfamilies of cytochrome P-450. This was most frequently true about CYP1A (EROD, ethoxyresorufin-O-deethylase), CYP2B (PROD, pentoxyresorufin-O-deethylase) and CYP3A. These experiments, however, focused on mixtures in which the majority of ethers contained a smaller number of bromine atoms in the molecule, such as TetraBDE (BDE-47, BDE-77), PentaBDE (BDE-99, BDE-100), HexaBDE (BDE-153, BDE-154) and HeptaBDE (BDE-183) [18-22]. Our earlier studies have shown that PentaBDE administered to rats at single or repeated doses caused the imbalance of redox homeostasis and heme biosynthesis and also altered hepatic microsomal enzyme activities [23-25]. The porphyrogenic activity of PentaBDE and OctaBDE were also observed (after repeated administration to rats) [25,26]. Redox imbalance observed after PentaBDE administration has encouraged us to investigate octabromodiphenyl ether in this aspect. Therefore, our study aimed at analyzing the effect of OctaBDE on the selected parameters of oxidative stress after single and repeated administration of this compound to rats. Of all the parameters, reduced GSH and oxidized GSSG, as well as liver MDA and serum TAS levels play the most important role in monitoring of the redox homeostasis balance.

\section{MATERIAL AND METHODS}

\section{Animals}

Female Wistar rats of 190-230 g body weight (b.w.) from the breeding colony of the Medical University in Lodz (Poland) were used in the experiments. The animals were fed 
a standard pelletized Murigran diet, with tap water accessible ad libitum. The rats of the same age (3-month-old) were divided into groups of 4-5 animals each (four animals per control groups, 5 animals per experimental groups).

\section{Chemicals}

The administered OctaBDE was a mixture of polybrominated ethers: octa- $(65.7 \%)$, hepta- $(14.8 \%)$, hexa- $(1.7 \%)$, nona- and decaBDE (a total of $17.8 \%$ ). This mixture was synthesized at the Department of Radiation Chemistry of the Technical University of Lodz (Poland).

\section{Animal treatment}

The OctaBDE mixture, dissolved in sunflower oil (edible oil for human consumption, without antioxidant ingredients), was administered intragastrically (i.g.) by gavage, in single doses of 25,200 or $2000 \mathrm{mg} / \mathrm{kg}$ b.w., at a volume of $0.5 \mathrm{~cm}^{3}$ per $200 \mathrm{~g}$ of rat b.w. $\left(2.5 \mathrm{~cm}^{3} / \mathrm{kg}\right.$ b.w.). In the repeated exposure, the animals received single daily doses of $0.4 ; 2 ; 8 ; 40$ or $200 \mathrm{mg} / \mathrm{kg}$ b.w.

Two kinds of controls were used: "pure control," where rats were not dosed, and "oil control" in which only sunflower oil (vehicle) was administered at a volume of $2.5 \mathrm{~cm}^{3} / \mathrm{kg}$ b.w.

The animals were sacrificed under ether anesthesia by intracardiac puncture 4, 24, 48, and $120 \mathrm{~h}$ after single administration of OctaBDE, as well as after $24 \mathrm{~h}$ following 7, 14, 21 and 28 days of repeated exposure.

\section{Biochemical analysis}

The toxicity of OctaBDE was assessed by determining the following parameters:

- in serum - the activity of total glutathione S-transferase (GST), and total antioxidant status (TAS);

- in the liver - concentrations of glutathione reduced (GSH), oxidized (GSSG), total (GSH+GSSG), and of malondialdehyde (MDA, an indicator of lipid peroxidation), and GST activity.
Liver GSH concentration was determined using the colorimetric method described by Sedlak and Lindsay [27] based on the measurement of nonprotein thiol groups by a color reaction with Ellman's reagent.

The determination of total glutathione (GSSG+GSH) concentration (according to Jollow et al. [28]) in the liver involved GSSG reduction under the influence of glutathione reductase (GR) followed by GSH determination. The activity of total GST (EC 2.5.1.18) in the liver and serum was determined after Asaoka and Takahashi [29]. Glutathione transferase activity was assessed by determination of the number of nitro groups released from the substrate (o-dinitrobenzene) during a 15-min incubation at $37^{\circ} \mathrm{C}$. The method was based on the colorimetric determination of the reduced nitrite after diazo-coupling with $\mathrm{N}$-(1-naphthyl)-ethylenediamine and sulfanilamide. The reaction resulted in a colorful product that was determined spectrophotometrically at a wavelength of $540 \mathrm{~nm}$. Several products of the damage induced by oxidative stress can be measured, such as tiobarbituric acid reactive substances (TBARS) formed as a byproduct of lipid peroxidation. Malondialdehyde (MDA) is the largest pool of TBARS. Therefore, in this study, the measurement of MDA was used as the indicator of lipid peroxidation. The concentration of MDA in the liver was determined according to Uchiyama and Mihara [30]. The colorimetric measurement of MDA was based on the reaction of 1 aldehyde molecule with 2 molecules of thiobarbituric acid at low $\mathrm{pH}(2-3)$ and $95^{\circ} \mathrm{C}$ for $45 \mathrm{~min}$. The resultant pink color was extracted by n-butanol, and the absorbance at $532 \mathrm{~nm}$ was determined with a spectrophotometer. In each series of measurements, blank samples (reagent blank) and standard solutions were used to prepare calibration curve. Determinations were parallel to calibrations, which confirmed the linearity of methods.

The total antioxidant status (TAS) in serum was determined with the use of the ready-made test (NX 2332, Randox Laboratories Ransel). 


\section{Ethics}

All procedures for animal experimentation were carried out according to Polish guidelines for animal care [31]. The experiments were performed with the permission (Resolution No. 17/LB457/2009) of the Local Ethical Committee No. 9 for Experimentation on Animals, affiliated to the Medical University of Lodz, Poland.

\section{Statistics}

The SYSTAT for Windows software was used to analyze the results. The significance of differences for selected parameters was determined by Tukey's HSD multiple comparison test after using Bartlett's test to check the homogeneity of variance (ANOVA). In all statistical analyzes a value of $p<0.05$ was considered to indicate statistical significance.

\section{RESULTS}

Two control groups, "pure control" and "oil control" were used in the experiments. There were no statistical differences between the results obtained in the "pure control" groups of each section; therefore, they were pooled into 1 common control group and included in the statistical analysis of the results. A single dose of oil did not cause significant changes in the results and therefore oil control groups were pooled. Due to different number of doses $(7,14,21$ or 28$)$ of the medium (sunflower oil) the "oil control group" was not pooled after repeated dosing.

\section{Results after a single dose of OctaBDE}

After a single oral administration to rats of the OctaBDE at all 3 doses, reduced body weight gain was observed after $24 \mathrm{~h}$. At that time, a statistically significant decrease in body weight gain was noted: by almost $14 \mathrm{~g}$ (6.1\%) compared to the control after the dose of $200 \mathrm{mg} / \mathrm{kg}$, and by $19 \mathrm{~g}(8.4 \%)$ after the dose of $2000 \mathrm{mg} / \mathrm{kg}$. After the highest dose of OctaBDE, a significant decrease in this parameter (up to $27.5 \mathrm{~g}$, which was almost $13 \%$ compared to the control) until the end of the observation period (120 h) was maintained (data not shown). After a single dose of OctaBDE, lower GSH levels in the liver were not observed, which could indicate a hepatotoxic effect of the compound. However, an increase in GSH levels (up to 120-130\% of control values) coupled with elevated GSSG concentration in the liver could be observed $48 \mathrm{~h}$ after OctaBDE administration (Table 1). Significantly higher levels of this parameter (up to 190-245\% of the control) was found $120 \mathrm{~h}$ after administration.

After a single oral administration of the highest dose $(2000 \mathrm{mg} / \mathrm{kg}$ ) of OctaBDE, a significant (over 2-fold) increase in the concentration of MDA in the liver was also observed (Table 2).

The reduction in the total antioxidant status was transient (Table 2). After the 2 highest doses (200 and $2000 \mathrm{mg} / \mathrm{kg}$ ), the decrease in TAS was $27-30 \%$ below the control values, and it was most evident after $4 \mathrm{~h}$.

\section{Results after repeated administration of OctaBDE}

After repeated administration to rats of the sunflower oil (Figure 1) and OctaBDE at the lowest dose $(0.4 \mathrm{mg} / \mathrm{kg} /$ day for 21 and 28 days - data not shown), the changes in weight gain were not significant. After the 2 higher doses ( 2 and $8 \mathrm{mg} / \mathrm{kg} /$ day) the reduction of this parameter was noted only after 28 days of exposure (Figure 1). After 2 highest doses (40 and $200 \mathrm{mg} / \mathrm{kg} /$ day), significant reduction in the body weight gain was observed. After 21 and 28 days of exposure to OctaBDE at the dose of $200 \mathrm{mg} / \mathrm{kg} /$ day, this parameter was approximately $25-28 \%$ lower than in the control animals.

The concentration of GSH in the rat liver increased after repeated administration of OctaBDE (Table 3). The highest, dose-dependent increase, up to 110-135\% of control values, was observed after 7 days of exposure. This was followed by statistically significant increases maintained after doses of $8-200 \mathrm{mg} / \mathrm{kg} /$ day. 
Table 1. Concentrations of reduced (GSH), oxidized (GSSG) and total (GSH+GSSG) glutathione, and glutathione S-transferase (GST) activity in rat liver after single intragastric administration of octabromodiphenyl ether (OctaBDE)

\begin{tabular}{|c|c|c|c|c|}
\hline \multirow{2}{*}{$\begin{array}{l}\text { Dose of OctaBDE } \\
\quad(\mathrm{mg} / \mathrm{kg})\end{array}$} & \multicolumn{4}{|c|}{$\begin{array}{l}\text { Parameter vs. time after administration } \\
\qquad(\mathrm{M} \pm \mathrm{SD})\end{array}$} \\
\hline & $4 \mathrm{~h}$ & $24 \mathrm{~h}$ & $48 \mathrm{~h}$ & $120 \mathrm{~h}$ \\
\hline \multicolumn{5}{|c|}{$\begin{array}{l}\text { Total glutathione concentration (GSH+GSSG) } \\
\text { in the liver ( } \mu \mathrm{g} / \mathrm{g} \text { of tissue) }\end{array}$} \\
\hline pure control & \multicolumn{4}{|c|}{$8.39 \pm 0.99$} \\
\hline oil control & \multicolumn{4}{|c|}{$7.92 \pm 0.62$} \\
\hline 25 & $8.34 \pm 0.61$ & $8.31 \pm 0.27$ & $9.89 \pm 0.40^{\mathrm{ab}}$ & $9.49 \pm 0.92$ \\
\hline 200 & $8.54 \pm 0.46$ & $9.80 \pm 0.53^{\mathrm{bc}}$ & $10.06 \pm 0.44^{\mathrm{ab}}$ & $10.36 \pm 0.44^{\mathrm{ab}}$ \\
\hline 2000 & $9.08 \pm 0.72$ & $8.76 \pm 0.03^{\text {bcd }}$ & $10.53 \pm 1.02^{\mathrm{ab}}$ & $11.03 \pm 0.78^{\mathrm{ab}}$ \\
\hline \multicolumn{5}{|l|}{$\begin{array}{l}\text { GSH concentration in the liver } \\
(\mu \mathrm{g} / \mathrm{g} \text { of tissue })\end{array}$} \\
\hline pure control & \multicolumn{4}{|c|}{$6.47 \pm 0.85$} \\
\hline oil control & \multicolumn{4}{|c|}{$6.54 \pm 0.33$} \\
\hline 25 & $6.62 \pm 0.43$ & $6.55 \pm 0.40$ & $7.94 \pm 0.30^{\mathrm{ab}}$ & $6.00 \pm 0.43$ \\
\hline 200 & $7.22 \pm 0.352$ & $7.27 \pm 0.50$ & $8.49 \pm 0.55^{\mathrm{ab}}$ & $6.75 \pm 0.34$ \\
\hline 2000 & $7.44 \pm 0.57$ & $7.01 \pm 0.18$ & $8.53 \pm 0.82^{\mathrm{ab}}$ & $6.45 \pm 0.33$ \\
\hline \multicolumn{5}{|l|}{$\begin{array}{l}\text { GSSG concentration in the liver } \\
\quad(\mu \mathrm{g} / \mathrm{g} \text { of tissue })\end{array}$} \\
\hline pure control & \multicolumn{4}{|c|}{$1.85 \pm 0.64$} \\
\hline oil control & \multicolumn{4}{|c|}{$1.43 \pm 0.33$} \\
\hline 25 & $1.58 \pm 0.21$ & $1.76 \pm 0.66$ & $1.95 \pm 0.40$ & $3.45 \pm 0.53^{\mathrm{ab}}$ \\
\hline 200 & $1.39 \pm 0.22$ & $2.45 \pm 0.37^{b}$ & $1.93 \pm 0.28$ & $3.67 \pm 0.24^{\mathrm{ab}}$ \\
\hline 2000 & $1.57 \pm 0.24$ & $1.76 \pm 0.18$ & $2.00 \pm 0.43$ & $4.62 \pm 1.03^{\mathrm{ab}}$ \\
\hline \multicolumn{5}{|l|}{ GSH/GSSG ratio in the liver* } \\
\hline pure control & \multicolumn{4}{|c|}{$3.45 \pm 1.01$} \\
\hline oil control & \multicolumn{4}{|c|}{$4.69 \pm 0.90$} \\
\hline 25 & $4.19 \pm 0.35$ & $4.05 \pm 1.38$ & $4.22 \pm 0.95$ & $1.74 \pm 0.23^{\mathrm{ab}}$ \\
\hline 200 & $5.14 \pm 0.81$ & $3.03 \pm 0.60$ & $4.50 \pm 1.17$ & $1.83 \pm 0.17^{\mathrm{ab}}$ \\
\hline 2000 & $4.97 \pm 0.78$ & $4.06 \pm 0.63$ & $4.54 \pm 1.32$ & $1.51 \pm 0.45^{\mathrm{ab}}$ \\
\hline \multicolumn{5}{|l|}{$\begin{array}{l}\text { GST activity in the liver } \\
(\mathrm{nmol} / \mathrm{min} \times \mathrm{g} \text { of tissue })\end{array}$} \\
\hline pure control & \multicolumn{4}{|c|}{$88.00 \pm 9.83$} \\
\hline oil control & \multicolumn{4}{|c|}{$90.09 \pm 9.97$} \\
\hline 25 & $99.65 \pm 3.43$ & $84.92 \pm 5.23$ & $92.96 \pm 6.24$ & $93.76 \pm 4.16$ \\
\hline 200 & $102.10 \pm 4.80$ & $80.32 \pm 4.83$ & $92.26 \pm 8.49$ & $83.57 \pm 2.04$ \\
\hline 2000 & $98.40 \pm 7.11$ & $82.27 \pm 3.43$ & $90.31 \pm 7.72$ & $84.57 \pm 9.07$ \\
\hline
\end{tabular}

* The data have been expressed as mean values for individual results in study groups.

$\mathrm{M}$ - mean; SD - standard deviation.

Significantly different $(\mathrm{p} \leq 0.05)$ from: ${ }^{a}$ pure control animals; ${ }^{\mathrm{b}}$ oil control animals; ${ }^{\mathrm{c}}$ the group of rats given OctaBDE at a dose of $25 \mathrm{mg} / \mathrm{kg}$;

${ }^{d}$ the group of rats given OctaBDE at a dose of $200 \mathrm{mg} / \mathrm{kg}$. 
Table 2. Liver concentration of malondialdehyde (MDA) and serum total antioxidant status (TAS) in rats after single intragastric administration of octabromodiphenyl ether (OctaBDE)

\begin{tabular}{|c|c|c|c|c|}
\hline \multirow{2}{*}{$\begin{array}{l}\text { Dose of OctaBDE } \\
\quad(\mathrm{mg} / \mathrm{kg})\end{array}$} & \multicolumn{4}{|c|}{$\begin{array}{l}\text { Parameter vs. time after administration } \\
\qquad(\mathrm{M} \pm \mathrm{SD})\end{array}$} \\
\hline & $4 \mathrm{~h}$ & $24 \mathrm{~h}$ & $48 \mathrm{~h}$ & $120 \mathrm{~h}$ \\
\hline \multicolumn{5}{|l|}{$\begin{array}{l}\text { Liver concentration of MDA } \\
\text { (nmol/g of tissue) }\end{array}$} \\
\hline pure control & \multicolumn{4}{|c|}{$117.2 \pm 18.72$} \\
\hline oil control & \multicolumn{4}{|c|}{$115.9 \pm 13.31$} \\
\hline 25 & $152.3 \pm 22.16$ & $130.6 \pm 34.61$ & $133.9 \pm 37.13$ & $111.0 \pm 20.62$ \\
\hline 200 & $156.9 \pm 26.84$ & $133.5 \pm 8.98$ & $139.6 \pm 35.63$ & $140.5 \pm 42.29$ \\
\hline 2000 & $220.7 \pm 55.77^{\mathrm{ab}}$ & $243.3 \pm 19.98^{\mathrm{abcd}}$ & $185.9 \pm 66.50$ & $227.2 \pm 98.23^{\mathrm{ab}}$ \\
\hline \multicolumn{5}{|l|}{$\begin{array}{l}\text { Serum total antioxidant status } \\
\text { (TAS) }\left(\mathrm{mmol} / \mathrm{dm}^{3}\right)\end{array}$} \\
\hline pure control & \multicolumn{4}{|c|}{$0.589 \pm 0.041$} \\
\hline 25 & $0.565 \pm 0.028$ & $0.506 \pm 0.115$ & $0.56 \pm 0.014$ & $0.596 \pm 0.106$ \\
\hline 200 & $0.41 \pm 0.081^{\mathrm{ac}}$ & $0.513 \pm 0.100$ & $0.496 \pm 0.096$ & $0.513 \pm 0.053$ \\
\hline 2000 & $0.434 \pm 0.096^{\mathrm{ac}}$ & $0.475 \pm 0.040^{\mathrm{a}}$ & $0.493 \pm 0.041^{\text {ac }}$ & $0.540 \pm 0.065$ \\
\hline
\end{tabular}

Abbreviations as in Table 1.

The analysis revealed the fluctuation of GSSG concentrations in the liver (Table 3). However, the elevated GSSG concentration in the liver was evident after 28 days of OctaBDE administration. This was

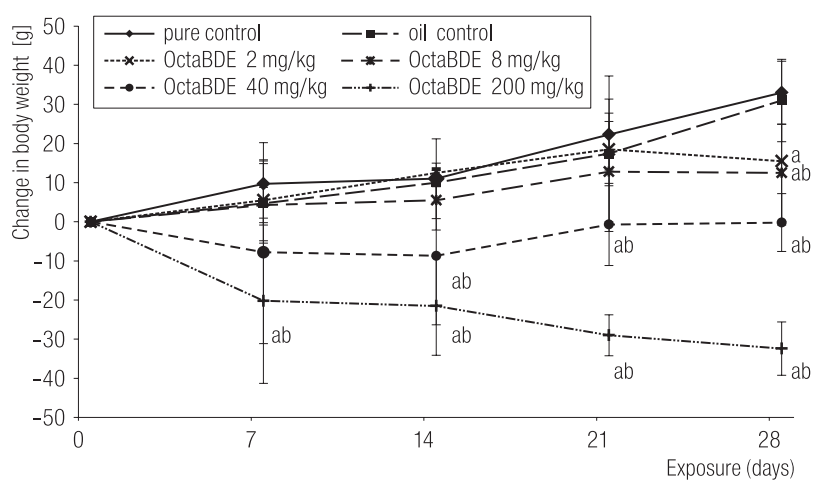

The results are expressed as $\mathrm{M} \pm \mathrm{SD}$.

Mean of the body weight at the start of OctaBDE administration (0. day): $213.7 \pm 10.2 \mathrm{~g}$.

Significantly different $(\mathrm{p}<0.05)$ from: a - pure control animals, $\mathrm{b}$ - oil control animals.

Fig. 1. Changes in body weight of rats after repeated, intragastric administration of octabromodiphenyl ether (OctaBDE) dose-dependent and ranged from 123 to $184 \%$ of the control values.

The highest concentration of GSSG in the liver was accompanied by significantly increased GST activity in this organ (Table 3). This increase reached $117-131 \%$ of control after administration of the mixture at $2-200 \mathrm{mg} / \mathrm{kg} /$ day.

The disturbed redox homeostasis in the rats after administration of OctaBDE was manifested by explicit increase in liver MDA concentration (Figure 2). Its 5-fold elevation was observed after 7 days of exposure to the highest dose $(200 \mathrm{mg} / \mathrm{kg} /$ day $)$ of OctaBDE and about 2-fold after 14 days of exposure to lower doses ( 8 and $40 \mathrm{mg} / \mathrm{kg} /$ day). A dose-dependent increase in the level of this parameter was also noted after 21 and 28 days of exposure.

The value of TAS in serum was analyzed also after repeated administration of OctaBDE to rats (Figure 3). The results showed that sunflower oil administered at repeated doses did not affect this parameter even after 28 days. The exposure of animals to OctaBDE caused the time- and dose-dependent reduction in the TAS value. The lowest 
Table 3. Concentrations of reduced (GSH), oxidized (GSSG) and total (GSH+GSSG) glutathione, and glutathione S-transferase (GST) activity in rat liver after repeated intragastric administration of octabromodiphenyl ether (OctaBDE)

\begin{tabular}{|c|c|c|c|c|}
\hline \multirow{2}{*}{$\begin{array}{l}\text { Dose of OctaBDE } \\
\quad(\mathrm{mg} / \mathrm{kg} / \mathrm{day})\end{array}$} & \multicolumn{4}{|c|}{$\begin{array}{l}\text { Parameter vs. time of exposure } \\
(\mathrm{M} \pm \mathrm{SD})\end{array}$} \\
\hline & 7 days & 14 days & 21 days & 28 days \\
\hline \multicolumn{5}{|c|}{$\begin{array}{l}\text { Total glutathione concentration (GSH+GSSG) } \\
\text { in the liver ( } \mu \mathrm{g} / \mathrm{g} \text { of tissue) }\end{array}$} \\
\hline pure control & \multicolumn{4}{|c|}{$8.37 \pm 0.76$} \\
\hline oil control & $9.89 \pm 0.71$ & $8.91 \pm 0.42$ & $7.75 \pm 0.23$ & $8.34 \pm 0.33$ \\
\hline 0.4 & & & $8.20 \pm 0.56$ & $8.78 \pm 0.23$ \\
\hline 2 & $9.18 \pm 0.26$ & $7.96 \pm 0.65$ & $8.27 \pm 0.37$ & $9.28 \pm 0.10^{\mathrm{abc}}$ \\
\hline 8 & $10.12 \pm 0.62^{\mathrm{ad}}$ & $8.55 \pm 0.46$ & $9.30 \pm 0.66^{b}$ & $9.46 \pm 0.37^{\mathrm{abc}}$ \\
\hline 40 & $10.54 \pm 0.87^{\text {ad }}$ & $10.33 \pm 0.91^{\text {abe }}$ & $9.34 \pm 0.36^{\mathrm{bcd}}$ & $10.48 \pm 0.48^{\text {abcde }}$ \\
\hline 200 & $11.06 \pm 1.60^{\text {ad }}$ & $9.80 \pm 0.52^{\text {abde }}$ & $8.14 \pm 0.79$ & $10.69 \pm 0.66^{\text {abcde }}$ \\
\hline \multicolumn{5}{|l|}{$\begin{array}{l}\text { GSH concentration in the liver } \\
\text { ( } \mu \mathrm{g} / \mathrm{g} \text { of tissue })\end{array}$} \\
\hline pure control & \multicolumn{4}{|c|}{$7.53 \pm 0.61$} \\
\hline oil control & $9.00 \pm 0.54^{\mathrm{a}}$ & $8.17 \pm 0.39$ & $7.25 \pm 0.22$ & $7.51 \pm 0.28$ \\
\hline 0.4 & & & $7.65 \pm 0.52$ & $7.73 \pm 0.19$ \\
\hline 2 & $8.28 \pm 0.22$ & $7.23 \pm 0.52$ & $7.50 \pm 0.12$ & $8.15 \pm 0.09^{b c}$ \\
\hline 8 & $8.95 \pm 0.20^{\mathrm{ad}}$ & $8.09 \pm 0.61$ & $8.59 \pm 0.52^{\mathrm{abd}}$ & $8.25 \pm 0.37^{\mathrm{bc}}$ \\
\hline 40 & $9.41 \pm 0.86^{\mathrm{ad}}$ & $9.48 \pm 0.76^{\text {abde }}$ & $9.03 \pm 0.31^{\mathrm{abcd}}$ & $8.99 \pm 0.60^{\mathrm{abcd}}$ \\
\hline 200 & $10.22 \pm 1.03^{\text {abde }}$ & $8.84 \pm 0.37^{\mathrm{ad}}$ & $7.46 \pm 0.15^{\mathrm{ef}}$ & $9.11 \pm 0.42^{\text {abcde }}$ \\
\hline \multicolumn{5}{|l|}{$\begin{array}{l}\text { GSSG concentration in the liver } \\
(\mu \mathrm{g} / \mathrm{g} \text { of tissue })\end{array}$} \\
\hline pure control & \multicolumn{4}{|c|}{$0.86 \pm 0.13$} \\
\hline oil control & $0.68 \pm 0.15$ & $0.73 \pm 0.05$ & $0.50 \pm 0.04$ & $0.83 \pm 0.05$ \\
\hline 0.4 & & & $0.54 \pm 0.19$ & $1.06 \pm 0.13^{b}$ \\
\hline 2 & $0.90 \pm 0.15$ & $0.74 \pm 0.15$ & $0.77 \pm 0.26$ & $1.14 \pm 0.14^{\mathrm{ab}}$ \\
\hline 8 & $1.17 \pm 0.46$ & $0.70 \pm 0.50$ & $0.71 \pm 0.20$ & $1.22 \pm 0.27^{b}$ \\
\hline 40 & $1.13 \pm 0.30^{\mathrm{b}}$ & $0.84 \pm 0.72$ & $0.36 \pm 0.12^{\text {ade }}$ & $1.50 \pm 0.20^{\mathrm{abcd}}$ \\
\hline 200 & $1.22 \pm 0.05^{\mathrm{abd}}$ & $0.97 \pm 0.64$ & $0.68 \pm 0.77$ & $1.58 \pm 0.24^{\mathrm{abcd}}$ \\
\hline \multicolumn{5}{|l|}{ GSH/GSSG ratio in the liver* } \\
\hline pure control & \multicolumn{4}{|c|}{$8.78 \pm 1.22$} \\
\hline oil control & $11.58 \pm 5.40$ & $11.17 \pm 1.53$ & $14.54 \pm 4.07$ & $9.06 \pm 0.23$ \\
\hline 0.4 & & & $15.23 \pm 4.36^{\mathrm{a}}$ & $7.41 \pm 0.93^{b}$ \\
\hline 2 & $9.56 \pm 1.34$ & $10.10 \pm 1.73$ & $10.84 \pm 4.43$ & $7.26 \pm 0.93^{b}$ \\
\hline 8 & $8.81 \pm 3.98$ & $12.86 \pm 7.76$ & $12.76 \pm 3.40$ & $7.98 \pm 1.55$ \\
\hline 40 & $8.80 \pm 2.62$ & $11.24 \pm 5.67$ & $25.03 \pm 11.47^{\mathrm{a}}$ & $6.13 \pm 1.14^{\mathrm{ab}}$ \\
\hline 200 & $8.58 \pm 0.64$ & $12.33 \pm 6.78$ & $10.97 \pm 8.77$ & $5.78 \pm 0.57^{\text {abce }}$ \\
\hline
\end{tabular}


Table 3. Concentrations of reduced (GSH), oxidized (GSSG) and total (GSH+GSSG) glutathione, and glutathione S-transferase (GST) activity in rat liver after repeated intragastric administration of octabromodiphenyl ether (OctaBDE) - cont.

\begin{tabular}{|c|c|c|c|c|}
\hline \multirow{2}{*}{$\begin{array}{l}\text { Dose of OctaBDE } \\
\quad(\mathrm{mg} / \mathrm{kg} / \text { day })\end{array}$} & \multicolumn{4}{|c|}{$\begin{array}{l}\text { Parameter vs. time of exposure } \\
\qquad(\mathrm{M} \pm \mathrm{SD})\end{array}$} \\
\hline & 7 days & 14 days & 21 days & 28 days \\
\hline \multicolumn{5}{|l|}{$\begin{array}{l}\text { GST activity in the liver } \\
(\mathrm{nmol} / \mathrm{min} \times \mathrm{g} \text { of tissue })\end{array}$} \\
\hline pure control & \multicolumn{4}{|c|}{$80.4 \pm 9.85$} \\
\hline oil control & $64.56 \pm 5.10^{\mathrm{a}}$ & $84.2 \pm 11.05$ & $89.0 \pm 5.05$ & $94.6 \pm 4.16$ \\
\hline 0.4 & & & $80.0 \pm 9.65$ & $90.2 \pm 2.70$ \\
\hline 2 & $60.10 \pm 4.09^{\mathrm{a}}$ & $87.9 \pm 4.42$ & $97.5 \pm 4.30^{\mathrm{a}}$ & $94.0 \pm 3.67^{\mathrm{a}}$ \\
\hline 8 & $66.60 \pm 10.08$ & $84.2 \pm 8.0$ & $78.7 \pm 11.03$ & $95.9 \pm 4.69^{\mathrm{a}}$ \\
\hline 40 & $63.10 \pm 6.85$ & $86.4 \pm 4.11$ & $79.8 \pm 10.98$ & $102.7 \pm 2.75^{\mathrm{abcd}}$ \\
\hline 200 & $63.60 \pm 9.15$ & $89.7 \pm 4.36$ & $98.9 \pm 11.58^{\mathrm{a}}$ & $105.6 \pm 3.39^{\mathrm{abcde}}$ \\
\hline
\end{tabular}

Significantly different $(\mathrm{p} \leq 0.05)$ from: ${ }^{\text {a }}$ pure control animals; ${ }^{\mathrm{b}}$ oil control animals; ${ }^{\mathrm{c}}$ group of rats given OctaBDE at $0.4 \mathrm{mg} / \mathrm{kg} / \mathrm{day} ;{ }^{\mathrm{d}}$ group of rats given OctaBDE at $2 \mathrm{mg} / \mathrm{kg} / \mathrm{day} ;{ }^{\mathrm{e}}$ group of rats given OctaBDE at $8 \mathrm{mg} / \mathrm{kg} / \mathrm{day} ;{ }^{\mathrm{f}}$ group of rats given OctaBDE at $40 \mathrm{mg} / \mathrm{kg} / \mathrm{day}$.

* The data have been expressed as mean values for individual results in study groups.

Other abbreviations as in Table 1.

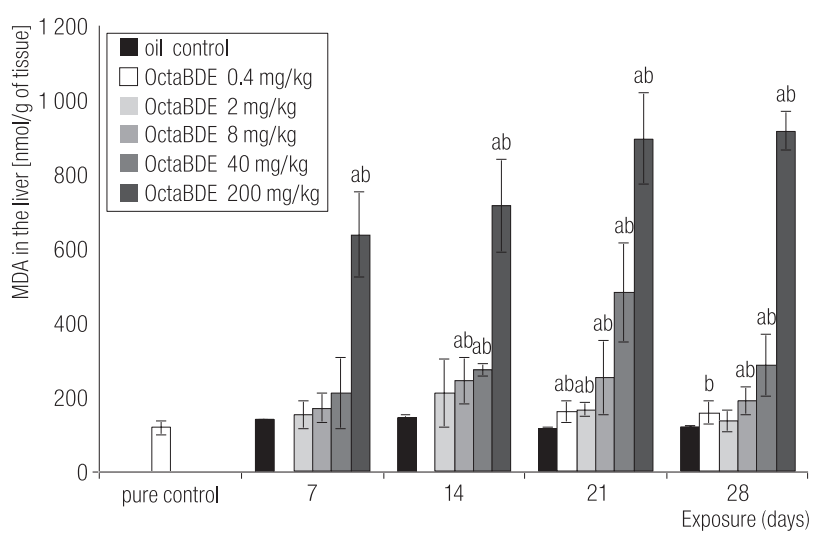

The results are expressed as $\mathrm{M} \pm \mathrm{SD}$.

Significantly different as in Figure 1.

Fig. 2. Liver concentration of MDA in rats after repeated, intragastric administration of octabromodiphenyl ether (OctaBDE)

dose $(0.4 \mathrm{mg} / \mathrm{kg} /$ day $)$ caused the decrease after 28 days and a dose of $2 \mathrm{mg} / \mathrm{kg} /$ day decreased the TAS value after 21 and 28 days of exposure. Higher doses of OctaBDE $(8,40$, and $200 \mathrm{mg} / \mathrm{kg} /$ day $)$ decreased TAS value after 7 days of exposure. The highest decrease (about 40\%) of this parameter was found 28 days after administration of OctaBDE at the 2 highest doses.

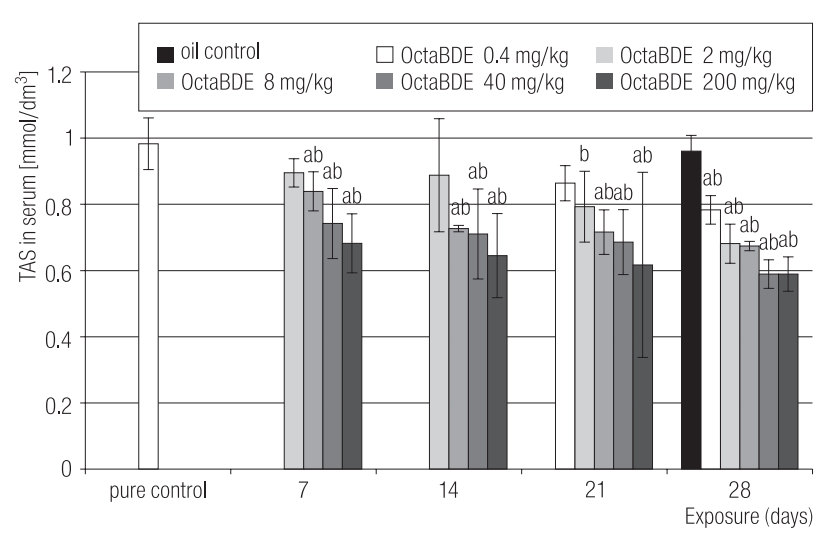

The results are expressed as $\mathrm{M} \pm \mathrm{SD}$.

Significantly different as in Figure 1.

Fig. 3. Serum total antioxidant status (TAS) in rats after repeated, intragastric administration of octabromodiphenyl ether (OctaBDE)

\section{DISCUSSION}

Polybrominated diphenyl ethers, used as flame retardants, are the mixtures containing ethers with varying degrees of bromination. The mixture of PBDEs tested in these experiments contained about $65.7 \%$ of isomers of octabromodiphenyl ethers. Until 2004, the commercially available preparations of OctaBDE, marketed under the following 
trade names: Bromkal 79-8 DE, DE-79 ${ }^{\mathrm{TM}}$, Tardex 80, and Saytex 111, were also the mixtures of various isomers of polybrominated diphenyl ethers.

They usually contained only 26-36\% of octabromodiphenyl ethers, while other isomers accounted for $42-58 \%$ of hepta-; up to $12 \%$ of penta- and hexa-; 8-14\% of nona-; and up to $2.1 \%$ of decabromodiphenyl ethers. In that mixture, bromine made up 79\% of its weight. OctaBDE comprises various isomers described in the literature as congeners numbered from 194 to 205 . The commercial mixtures of OctaBDE most frequently contained BDE-196, BDE-197 and BDE-203 [2].

The decrease of body weight gain during the experiment, compared to the control group, provides evidence that the xenobiotics exert an adverse effect on laboratory animals. This statistically significant effect was observed after a single oral administration of OctaBDE to rats at the highest dose. A significant reduction in the body weight gain was also noted after repeated administration of OctaBDE at 2 highest doses (40 and $200 \mathrm{mg} / \mathrm{kg} /$ day). After the doses of 2 and $8 \mathrm{mg} / \mathrm{kg} /$ day, body weight gain reduction was noted only after 28 days of exposure (Figure 1).

To asses the toxicity of OctaBDE in rats receiving single and repeated doses of OctaBDE, the same biochemical indicators were used as in previous experiments, in which similar assessment of PentaBDE and DecaBDE had been performed [23,24]. After comparing the toxicity of PentaBDE and DecaBDE administered at repeated doses, it was found that one of them (PentaBDE) demonstrated a substantial effect on the selected parameters of oxidative stress [23]. Such effects were also observed after a single dose of PentaBDE [24]. These observations inspired the authors to carry out a similar analysis for OctaBDE, the least known polybromodiphenyl ether. In the state of oxidative stress, namely the enhancement of oxidative reactions, excess amounts of active forms of oxygen (reactive oxygen species, ROS), including free radicals, emerge in the cells. The microsomal electron transport chain, which is implicated in the metabolism of xenobiotics, is a major source of free radicals [32,33]. Oxidative stress is manifested by the imbalance between the production of reactive oxygen species and the capacity of antioxidant mechanisms to neutralize them. This may be due to the increased ROS generation and/or a weaker antioxidant defense. The determination of total antioxidant status seems to be the least invasive way to assess the balance between oxidants and antioxidants in the body. The reduction in the TAS value observed after both single (Table 2) and repeated (Figure 3) administration of OctaBDE indicates a weakened antioxidant defense and an increase in oxidative stress.

The produced reactive oxygen species exert an adverse effect on the transformation of fatty acids in cell membranes. They can also initiate the process of lipid peroxidation. The formation of malondialdehyde is an indicator of the lipid peroxidation level, and thus an indicator of the development of oxidative stress [34,35]. Considerably elevated concentration of MDA in the liver was observed following single (Table 2) and repeated (Figure 2) administration of OctaBDE to rats.

Low molecular antioxidants (e.g., uric acid, $\beta$-carotene, vitamins $\mathrm{A}, \mathrm{E}$ and $\mathrm{C}$ ), antioxidant enzymes (superoxide dismutase, SOD, catalase, CAT), and enzymes involved in glutathione changes (glutathione peroxidase (GPx), glutathione reductase, and glutathione S-transferase) prevent the formation of reactive oxygen species. Their highest activity is observed in hepatocytes, one of the cells most exposed to oxygen radicals $[32,35]$.

Reduced glutathione (GSH), owing to the nucleophilic $\mathrm{SH}$ group, plays a crucial role in the detoxification of both free radicals and reactive metabolites [32]. Due to the ability to reduce peroxides and to maintain an appropriate condition of $\mathrm{SH}$ groups in proteins, GSH is the 1st line of cellular defense against the effects of oxidative stress. The reduction of GSH concentration is an initial effect of the body's defense against 
oxidative stress. This may lead to a later increase in its concentration, which is caused by a feedback control. Such changes were noted after single (statistically significant after $48 \mathrm{~h}$, Table 3 ) and repeated administration of OctaBDE at 8-200 mg/kg/day (Table 3). The oxidative stress may generate the increase in GSSG concentration. This is dangerous, because GSSG can react with protein sulfhydryl groups and form disulfides, which usually leads to an impairment of the function of proteins [32,35]. Statistically significant increase in GSSG concentration occurred $120 \mathrm{~h}$ after a single dose of OctaBDE (Table 1) and 28 days after administration of this compound at all doses (Table 3 ).

Glutathione S-transferases are enzymes whose formation, besides other metabolic enzymes of phase II (for example, UDP-glucuronyl-transferase), might be under the control of the aryl hydrocarbon $(\mathrm{Ah})$ receptor [36,37]. In addition to the participation in the second phase of the transformation of xenobiotics, GST may also be involved in the detoxification of lipid peroxidation products, which helps to protect the body against oxidative stress. The elevated levels of GST in the liver after 28 days of OctaBDE administration at doses of 2-200 mg/kg/day may trigger the body's defense mechanisms against oxidative stress (Table 3 ).

The results of these experiments indicate that both single and repeated administration of OctaBDE influenced the level of selected oxidative stress parameters. Two major non-enzymatic indicators - MDA and TAS - proved to be the most useful to assess the effect on the parameters of oxidative stress. After a single dose of the compound, the redox homeostasis was disturbed, as evidenced by the reduction of TAS in serum, the increased GSH and GSSG concentrations and the enhanced GST activity in the liver. These effects were observed already after the lowest dose (25 mg/kg b.w.). Therefore, this dose can be adopted as the lowest observed adverse effect level (LOAEL) (Table 4).
Table 4. No observed adverse effect level (NOAEL) and lowest observed adverse effect level (LOAEL) after repeated administration of octabromodiphenyl ether (OctaBDE)

\begin{tabular}{lcc}
\hline \multirow{1}{*}{ Parameter } & \multicolumn{2}{c}{$\begin{array}{c}\text { Repeated administration } \\
(\mathrm{mg} / \mathrm{kg} / \mathrm{day})\end{array}$} \\
\cline { 2 - 3 } & NOAEL & LOAEL \\
\hline Changes in body weight & 0.4 & 2.0 \\
MDA concentration in the liver & - & $0.4^{*}$ \\
TAS in serum & - & $0.4^{*}$ \\
GSH in the liver & 0.4 & 2.0 \\
GSSG in the liver & - & $0.4^{*}$ \\
GST in the liver & 0.4 & 2.0 \\
\hline
\end{tabular}

Abbreviations as in Tables 2 and 3.

* The lowest dose in this experiment was $0.4 \mathrm{mg} / \mathrm{kg} /$ day.

Repeated administration of OctaBDE caused the increase of MDA concentration in the liver, the reduction of TAS in serum, the increase of GSSG concentration and GST activity in the liver and the reduction of GSH/GSSG ratio in the liver (Table 3). The changes in selected parameters, such as the increase in GSH concentration and GST activity in the liver, indicate the initiation of the defense mechanisms in the body. However, this endogenous antioxidant system was not able to successfully compensate for the excessive lipid peroxidation (e.g., increase of liver MDA concentration) and effectively protect against the effects of oxidative stress. The analyses of the changes in these parameters (Table 4) show that even the lowest dose $(0.4 \mathrm{mg} / \mathrm{kg} /$ day $)$ of the administered compound resulted in the redox imbalance, therefore this dose can also be accepted as LOAEL. That dose was observed to produce, among other things, the increase in MDA and GSSG concentrations in the liver, and the decrease in the TAS value in serum.

The comparison of the results of our experiments intended to assess the toxicity of PentaBDE and OctaBDE showed that the presence of a comparable amount of respective isomers in the mixtures played an important role. The mixture of PentaBDE contained $63.2 \%$ isomers of the pentabromodiphenyl ether and OctaBDE mixture contained 65.7\% 
isomers of the octabromodiphenyl ether. The results of OctaBDE toxicity studies carried out by the manufacturers of commercial products, cited in [2] accessible in the relevant literature were related to the commercial products in which isomers of octabromodiphenyl ethers accounted usually for $1 / 3$ of the total mixture $[9,16,17]$. The toxic effects of commercial OctaBDE may also be affected by other polybrominated diphenyl ethers, such as HeptaBDE, which accounted for $42-58 \%$ of the total mixture.

\section{CONCLUSIONS}

The data obtained from our studies indicate a similar nature of toxic effects of 2 mixtures: PentaBDE and OctaBDE. PBDEs were used in different resins, polymers, and substances at levels ranging from 5 to $30 \%$. EU Directive 2011/65/EU [38] on the restriction of the use of certain hazardous substances in equipment is currently binding. It sets the maximum concentration of PBDEs in homogeneous material at $0.1 \%$. It should, however, be borne in mind that, although those compounds are classified as POPs, they are still used in the production of electrical and electronic equipment. The fact that those compounds are characterized by a considerable persistence and that under certain conditions (e.g., uncontrolled burning) may be converted into dioxins and furans makes them very dangerous to the natural environment.

\section{REFERENCES}

1. Directive 2003/11/EC of the European Parliament and of the Council of 6 February 2003 amending for the 24th time Council Directive 76/769/EEC relating to restrictions on the marketing and use of certain dangerous substances and preparations (pentabromodiphenyl ether and octabromodiphenyl ether) (Feb 15, 2003). Available from: http://eur-lex. europa.eu/legal-content/EN/TXT/PDF/?uri=CELEX:32003 L0011\&from $=$ EN.
2. European Union. Summary risk assessment report. Diphenyl ether, octabromo derivative (octabromodiphenyl ether). CAS No.: 32536-52-0, EINCES No.: 251-087-9. Joint Research Centre, Institute for Health and Consumer Protection, European Chemical Bureau, European Commission: Ispra; 2003 [cited 2014 Jan 15]. Available from: http://echa.europa.eu/documents/10162/01e59081-67a9473b-8093-4df8bf646ee5.

3. Law RJ, Allchin CR, deBoer J, Covaci A, Herzke D, Lepom P, et al. Levels and trends of brominated flame retardants in the European environment. Chemosphere. 2006;64(2):187-208, http://dx.doi.org/10.1016/j.chemosphere.2005.12.007.

4. Kohler M, Zennegg M, Bogdal C, Gerecke AC, Schmid P, Heeb NV, et al. Temporal trends, congener patterns, and sources of octa-, nona-, and decabromodiphenyl ethers (PBDE) and hexabromocyclododecanes (HBCD) in Swiss lake sediments. Environ Sci Technol. 2008;42(17):6378-84, http://dx.doi.org/10.1021/es702586r.

5. Gauthier LT, Hebert CE, Weseloh DVC, Letcher RJ. Dramatic changes in the temporal trends of polybrominated diphenyl ethers (PBDEs) in herring gull eggs from the Laurentian Great Lakes: 1982-2006. Environ Sci Technol. 2008;42(5):1524-30.

6. Costa LG, Giordano G, Tagliaferri S, Caglieri A, Mutti A. Polybrominated diphenyl ether (PBDE) flame retardants: Environmental contamination, human body burden and potential adverse health effects. Acta Biomed. 2008;79(3): 172-83.

7. Schecter A, Colacino J, Palet K, Kannan K, Yun SH, Haffner D, et al. Polybrominated diphenyl ether levels in foodstuffs collected from three locations from the United States. Toxicol Appl Pharmacol. 2010;243(2):217-24, http://dx.doi. org/10.1016/j.taap.2009.10.004.

8. Bi X, Thomas GO, Jones KC, Qu W, Sheng G, Martin FL, et al. Exposure of electronics dismantling workers to polybrominated diphenyl ethers, polychlorinated biphenyls, and organochloride pesticides in South China. Environ Sci Technol. 2007;41(16):5647-53. 
9. Zhou T, Ross DG, DeVito MJ, Crofton KM. Effects of short-term in vivo exposure to polybrominated diphenyl ethers on thyroid hormones and hepatic enzyme activities in weanling rats. Toxicol Sci. 2001;61(1):76-82, http:// dx.doi.org/10.1093/toxsci/61.1.76.

10. Zhang Y, Guo GC, Han X, Zhu C, Kilfoy BA, Zhu Y, et al. Do polybrominated diphenyl ethers (PBDEs) increase the risk of thyroid cancer? Biosci Hypotheses. 2008;1(4):195-9, http://dx.doi.org/10.1016/j.bihy.2008.06.003.

11. Wang H, Zhang Y, Liu Q, Wang F, Nie J, Qian Y. Examining the relationship between brominated flame retardants (BFR) exposure and changes of thyroid hormone levels around e-waste dismantling sites. Int J Hyg Environ Health. 2010;213(5):369-80, http://dx.doi.org/10.1016/j.ijh en.2010.06.004.

12. Jugan ML, Levi Y, Blondeau JP. Endocrine disruptors and thyroid hormone physiology. Biochem Pharmacol. 2010; 79(7):939-47, http://dx.doi.org/10.1016/j.bcp.2009.11.006.

13. Darnerud PO. Brominated flame retardants as possible endocrine disrupters. Ind J Androl. 2008;31(2):152-60, http://dx.doi.org/10.1111/j.1365-2605.2008.00869.x.

14. Chao HR, Shy CG, Wang SL, Chen SCC, Koh TW, Chen FA, et al. Impact of non-occupational exposure to polybrominated diphenyl ethers on menstruation characteristics of reproductive-age females. Environ Int. 2010;36(7):728-35, http://dx.doi.org/10.1016/j.envint.2010.05.007.

15. Viberg H, Johansson N, Fredriksson A, Eriksson J, Marsh G, Eriksson P. Neonatal exposure to higher brominated diphenyl ethers, hepta-, octa-, or nonabromodiphenyl ether, impairs spontaneous behavior and learning and memory functions of adult mice. Toxicol Sci. 2006;92(1): 211-8, http://dx.doi.org/10.1093/toxsci/kfj196.

16. Carlson GP. Introduction of xenobiotic metabolism in rats by brominated diphenyl ethers administered for 90 days. Toxicol Lett. 1980;6(3):207-15, http://dx.doi.org/10.1016/ 0378-4274(80)90193-9.

17. Carlson GP. Introduction of xenobiotic metabolism in rats by short-term administration of brominated diphenyl ethers.
Toxicol Lett. 1980;5(1):19-25, http://dx.doi.org/10.1016/ 0378-4274(80)90143-5.

18. Chen G, Bunce NJ. Polybrominated diphenyl ethers as Ah receptor agonists and antagonists. Toxicol Sci. 2003;76(2): 310-20, http://dx.doi.org/10.1093/toxsci/kfg236.

19. Peters AK, Nijmeijer S, Gradin K, Backlund M, Bergman A, Poellinger $\mathrm{L}$, et al. Interaction of polybrominated diphenyl ethers with the aryl hydrocarbon receptor pathway. Toxicol Sci. 2006;92(1):133-42, http://dx.doi.org/10.1093/toxsci/ kfj186.

20. Sanders JM, Burka LT, Smith CS, Black W, James R, Cunningham ML. Differential expression of CYP 1A, 2B, and 3A genes in the $\mathrm{F} 344$ rat following exposure to a polybrominated diphenyl ether mixture or individual components. Toxicol Sci. 2005;88(1):127-33, http://dx.doi.org/10.1093/toxsci/kfi288.

21. Talsness CE. Overview of toxicological aspects of polybrominated diphenyl ethers: A flame-retardant additive in several consumer products. Environ Res. 2008;108(2):158-67.

22. Öberg M, Westerholm E, Fattore E, Stern E, Hanberg A, Haglund A, et al. Toxicity of Bromkal 70-5DE, a technical mixture of polybrominated diphenyl ethers, following $28 \mathrm{~d}$ of oral exposure in rats and impact of analysed impurities. Chemosphere. 2010;80(2):137-43, http://dx.doi. org/10.1016/j.chemosphere.2010.04.006.

23. Bruchajzer E, Frydrych B, Sporny S, Szymańska JA. Toxicity of penta- and decabromodiphenyl ethers after repeated administration to rats: A comparative study. Arch Toxicol. 2010;84(4):287-99, http://dx.doi.org/10.1007/s00204-0090495-y.

24. Bruchajzer E, Frydrych B, Sporny S, Szymańska JA. The effect of short-term intoxication of rats with pentabromodiphenyl ether (in mimic commercial products). Hum Exp Toxicol. 2011;30(5):363-78, http://dx.doi.org/ 10.1177/0960327110371261.

25. Bruchajzer E. Porphyrogenic effect of pentabromodiphenyl ether after repeated administration to rats. Arch Toxicol. 2011;85(8):965-74, http://dx.doi.org/10.1007/s00204010-0621-x. 
26. Bruchajzer E, Frydrych B, Szymańska JA. Octabromodiphenyl ether - porphyrogenicity after repeated administration to rats. Int J Occup Med Environ Health. 2012;25(4): 392-403, http://dx.doi.org/10.2478/S13382-012-0055-1.

27. Sedlak T, Lindsay RH. Estimation of total protein bound and non-protein sulfhydryl groups in tissue with Ellman's reagent. Anal Biochem. 1968;25(1):192-205.

28. Jollow DJ, Mitchell JR, Zampaglione N, Gilette JR. Bromobenzene-induced liver necrosis. Protective role of glutathione and evidence for 3,4-bromobenzene oxide as the hepatotoxic metabolite. Pharmacology. 1974;11(3):151-69.

29. Asaoka K, Takahashi K. A colorimetric assay of glutathione S-transferase using o-dinitrobenzene as a substrate. J Biochem. 1983;94(5):1685-8.

30. Uchiyama M, Mihara M. Determination of malondialdehyde precursor in tissues by thiobarbituric acid test. Anal Biochem. 1978;86(1):271-8, http://dx.doi.org/10.1016/00032697(78)90342-1.

31. [Law of 21 January 2005 on animal experiments. J Laws 2005 No. 33, item 289]. Polish.

32. Lushchak VI. Glutathione homeostasis and functions: Potential targets for medical interventions. J Amino Acids. 2012, http://dx.doi.org/10.1155/2012/736837.
33. Zangar RC, Davydov DR, Verma S. Mechanisms that regulate production of reactive oxygen species by cytochrome P450. Toxicol Appl Pharmacol. 2004;199(3):316-31, http:// dx.doi.org/10.1016/j.taap.2004.01.018.

34. Del Rio D, Stewart AJ, Pellegrini N. A review of recent studies on malondialdehyde as toxic molecule and biological marker of oxidative stress. Nutr Metab Cardiovasc Dis. 2005;15(4): 316-28, http://dx.doi.org/10.1016/j.numecd.2005.05.003.

35. Urso ML, Clarkson PM. Oxidative stress, exercise, and antioxidant supplementation. Toxicology. 2003;189(1):41-54, http://dx.doi.org/10.1016/S0300-483X(03)00151-3.

36. Wada T, Gao J, Xie W. PXR and CAR in energy metabolism. Trends Endocrin Metabol. 2009;20(6):273-9, http://dx.doi. org/10.1016/j.tem.2009.03.003.

37. Kretschmer XC, Baldwin WS. CAR and PXR: Xenosensors of endocrine disrupters? Chem Biol Interact. 2005;155(3): 111-28, http://dx.doi.org/10.1016/j.cbi.2005.06.003.

38. Directive 2011/65/EU of the European Parliament and of the Council of 8 June 2011 on the restriction of the use of certain hazardous substances in electrical and electronic equipment. Official Journal of the European Union L 174/88; 1.7.2011 (Jul 1, 2011). Available from: http://www.linak.dk/corporate/ pdf/english/misc/rohs\%20directive.pdf.

This work is available in Open Access model and licensed under a Creative Commons Attribution-NonCommercial 3.0 Poland License - http://creativecommons.org/ licenses/by-nc/3.0/pl/deed.en. 